\title{
STRATEGI PENGEMBANGAN USAHA PETERNAKAN DAN PENGOLAHAN SUSU KAMBING DI GOATZILLA FARM
}

\author{
Development Strategy Business of Livestock and Milk Processing in \\ The Goatzilla Farm
}

\author{
Anang Febri Prasetyo dan Nurkholis \\ Jurusan Peternakan, Politeknik Negeri Jember \\ Email: anangfebri@polije.ac.id
}

\begin{abstract}
INTISARI
Penelitian ini bertujuan untuk menganalisis strategi pengembangan usaha peternakan dan pengolahan produk susu kambing di Goatzilla Farm, Kabupaten Lumajang, Jawa Timur. Penelitian ini merupakan penelitian diskriptif kuantitatif. Metode pengambilan data dengan survei menggunakan kuesioner. Data dianalisis menggunakan matrik SWOT untuk mengetahui peluang dan tantangan usaha di Goatzilla Farm. Hasil penelitian menggunakan analisis SWOT. Strategi alternatif yang direkomendasikan dalam usaha Goatzilla Farm adalah Strategi SO (Strengths Opportunities) yakni strategi keunggulan komparatif, mengoptimalkan dan mengembangkan kemampuan internal, serta memanfaatkan teknologi informasi untuk meningkatkan kualitas produk. Hasil penelitian menunjukkan perlu adanya kerjasama dengan pemerintah, peternak, dan jaringan distribusi untuk menyediakan bahan baku dan meningkatkan penjualan produk. Ancaman yang perlu diwaspadai oleh Goatzilla Farm adalah perizinan yang perlu disegerakan untuk memperkuat bargaining position. Tanpa adanya perizinan yang memadai dapat mengancam keberlangsungan usaha yang sedang dijalankan.
\end{abstract}

Kata kunci: Kambing Perah, Susu Kambing, Strategi Pengembangan

\begin{abstract}
This study aimed to analyze the development strategy of business and goat milk processing in the Goatzilla Farm, Lumajang, East Java. This research was descriptive. Methods of data by surveys using questionnaires. Data were analyzed by SWOT matrix to find out opportunities and threats in Goatzilla Farm. The results of the study used SWOT analysis. Alternative strategies recommendated in the Goatzilla Farm were SO strategies (Strength Opportunities), namely comparative strategy primacy, efficiency and internal development, and information technology to improve product quality. The results of the study showed to need cooperation with the government, farmers, and distribution networks to provide raw materials and increased product sales. The threat of Goatzilla Farm needed to watch out for was licensing which was processed immediately to support a bargaining position. There was no sufficient licensing, it could threat the sustainability of the business.
\end{abstract}

Keywords: Dairy Goat, Goat Milk, Development Strategy

\section{PENDAHULUAN}

Permintaan pasar akan susu kambing mulai meningkat beberapa tahun terakhir ini, tetapi belum dapat terpenuhi akibat produksi yang masih terbatas. Hal ini selain disebabkan masih rendahnya produktivitas kambing perah yang ada, juga disebabkan populasi kambing perah yang masih sedikit. Permintaan susu kambing yang meningkat seiring dengan pertambahan penduduk, peningkatan pendapatan, perbaikan tingkat 
pendidikan, urbanisasi, perubahan gaya hidup (life style) dan peningkatan kesadaran akan gizi seimbang.

Kambing PE merupakan komoditas baru di Indonesia yang memiliki prospek pengembangan yang baik. Umumnya kambing ini lebih dominan digunakan sebagai sumber daging dibandingkan dengan sumber susu. Salah satu daerah pengembangan kambing perah di indonesia adalah di Kabupaten Lumajang dengan kambing PE Senduro. Kambing Senduro melalui Keputusan Menteri Pertanian Republik Indonesia Nomor 1055/Kpts/SR.120/10/2014 telah ditetapkan sebagai Plasma Nutfah Indonesia (Menteri pertanian, 2014).

Populasi kambing Senduro tahun 2018 banyak ditemui di Kecamatan Senduro sebanyak 23.335 ekor dan Kecamatan Pasrujambe 16.401 ekor (Dinas Pertanian Kabupaten Lumajang, 2018). Pengembangan kambing Senduro didukung dengan potensi alam yang sangat mendukung. Kedua kecamatan tersebut berada di bawah lereng gunung Semeru yang memiliki daya dukung ketersediaan makanan ternak

Salah satu usaha ternak kambing PE Senduro yang berada di Kabupaten Lumajang adalah Goatzilla Farm. Goatzilla Farm merupakan peternakan kambing PE Senduro yang melakukan usaha di bidang pembibitan kambing, penghasil susu kambing, dan produk olahan susu kambing. Peternakan ini telah menjadi pelopor di Kabupaten Lumajang dalam usaha pengolahan produk susu kambing. Goatzilla Farm telah memproduksi berbagai produk berbahan baku susu kambing diantaranya susu pasteurisasi, yogurt, kefir, sabun susu, dan masker susu kambing. Selain itu Goatzilla Farm memanfaatkan peternakan dan produk olahan sebagai sarana agrowisata peternakan yang sangat menarik. Hal ini mendorong peneliti untuk mengetahui lebih jauh mengenai prospek usaha peternakan yang dijalankan oleh Goatzilla Farm.

Permasalahan yang ada di lokasi Goatzilla Farm berdasarkan latar belakang pada penelitian ini, yaitu: a) bagaimana prospek usaha ternak kambing PE Senduro di Goatzilla Farm; b) startegi apakah yang dilakukan untuk pengembangan ternak kambing PE Senduro di goatzilla farm; dan c) bagaimana strategi pemasaran produkproduk di Goatzilla Farm.

Penelitian ini bertujuan untuk menjelaskan dan mendiskripsikan prospek usaha ternak kambing PE Senduro, yaitu: memperoleh informasi tentang prospek usaha ternak kambing PE Senduro, menganalisis strategi pengembangan usaha ternak kambing PE Senduro, dan menganalisi strategi pemasaran produk di Goatzilla Farm.

\section{MATERI DAN METODE}

Penelitian ini bersifat deskriptif yang akan menelusuri secara mendalam mengenai objek penelitian. Nazir (2003) menjelaskan bahwa metode deskriptif adalah suatu metode dalam meneliti suatu kelompok. Penetapan lokasi penelitian diambil secara purposive berdasarkan pertimbangan-pertimbangan tertentu (Singarimbun dan Effendi, 1995). Dalam hal ini pertimbangannya karena pada peternakan Goatzilla Farm mampu mengembangkan produk olahan susu kambing.

Pengumpulan data menggunakan metode survei (Singarimbun dan Effendi, 1995). Metode ini dipilih karena dinilai lebih tepat dan mampu mengumpulkan informasi yang lebih dalam. Responden diberikan beberapa pertanyaan dalam bentuk daftar pertanyaan (kueisioner) yang dipandu oleh tenaga pencacah (surveyor). Data yang digunakan dalam penelitian ini adalah data primer dan data sekunder sesuai dengan kebutuhan penelitian. Data hasil penelitian yang diambil kemudian dianalisis dengan menggunakan matrik SWOT untuk mengetahui peluang dan tantangan usaha di Goatzilla Farm (Gambar 1). Metode yang digunakan dalam penelitian ini adalah sebagai berikut: 
1. Analisis internal dilakukan untuk memperoleh faktor kekuatan yang dapat dimanfaatkan dan faktor kelemahan yang harus diatasi. Faktor tersebut dievaluasi dengan menggunakan Matriks IFAS (intenal factor analysis summary) (Rangkuti, 2006).

2. Analisis eksternal menggunakan matriks EFAS (External Factor Analysis Summary) (Rangkuti, 2006).

3. Untuk menentukan alternatif strategi pengembangan usaha susu kambing Goatzilla Farm di Kecamatan Senduro, Kabupaten Lumajang digunakan analisis faktor internal dan eksternal yang selanjutnya dianalisis menggunakan analisis SWOT.

\section{HASIL DAN PEMBAHASAN}

\section{Profil Usaha di Goatzilla Farm}

Goatzilla Farm merupakan usaha peternakan milik keluarga, dengan tujuan awal pemeliharan ternak untuk produksi susu dan daging. Usaha peternakan yang dijalankan dapat berkembang dengan baik, ditandai dengan jumlah ternak yang dipelihara mencapai 50 ekor. Meningkatnya jumlah ternak dan hasil produksi susu, mendorong keluarga peternak untuk mengembangkan usahanya dengan mengolah susu kambing yang dihasilkan menjadi beberapa produk. Pengembangan produk ini didasari oleh semakin meningkatnya produksi susu, yang tidak terserap pasar.

\begin{tabular}{|l|c|c|}
\hline \multirow{2}{*}{ EKSTERNAL } & \multicolumn{2}{c|}{ INTERNAL } \\
\cline { 2 - 3 } & $\begin{array}{c}\text { STRENGTH (S) } \\
\text { Faktor kekuatan internal }\end{array}$ & $\begin{array}{c}\text { WEAKNESS (W) } \\
\text { Faktor kelemahan internal }\end{array}$ \\
\hline $\begin{array}{l}\text { OPPORTUNITIES (O) } \\
\text { Faktor peluang eksternal }\end{array}$ & $\begin{array}{c}\text { STRATEGI (SO) } \\
\text { Strategi yang menggunakan } \\
\text { kekuatan untuk } \\
\text { memanfaatkan peluang }\end{array}$ & $\begin{array}{c}\text { Strategi yang mengatasi } \\
\text { kelemahan dengan } \\
\text { memanfaatkan peluang }\end{array}$ \\
\hline $\begin{array}{l}\text { THREATS (T) } \\
\text { Faktor ancaman eksternal }\end{array}$ & $\begin{array}{c}\text { STRATEGI (ST) } \\
\text { Strategi yang menggunakan } \\
\text { kekuatan untuk menghindari } \\
\text { ancaman }\end{array}$ & $\begin{array}{c}\text { STRATEGI (WT) } \\
\text { Strategi yang meminimalkan } \\
\text { keleman dan menghindari } \\
\text { ancaman }\end{array}$ \\
\hline
\end{tabular}

Gambar 1. Matrix SWOT (Rangkuti, 2006)

Susu kambing terkenal memiliki banyak manfaat bagi manusia, hal ini yang mendasari Gotzilla Farm menekuni usaha ternak kambing. Harga susu kambing di tingkat peternak hanya berkisar antara Rp15.000,00/liter padahal di konsumen akhir harga dapat mencapai Rp25.000,00/liter (Tabel 1). Harga susu kambing jauh di atas harga susu sapi di daerah Lumajang yang hanya berkisar Rp. 6.000,00/liter.

Banyaknya peternak kambing di wilayah tersebut, dapat menjadi ancaman bagi peternak kambing itu sendiri, dengan melimpahnya produksi susu akan menurunkan harga susu. Hal ini juga telah terjadi pada peternak disekitar peternakan Gotzilla Farm. Bagi Gotzilla Farm justru menjadi peluang yang menarik untuk dapat menjadi leader di kawasan tersebut dengan cara mengolah susu menjadi produk yang dapat meningkatkan nilai ekonomis susu. Adanya produk olahan akan meningkatkan nilai susu kambing, dan mengubah pandangan orang bahwa susu kambing memiliki aroma yang khas (Khoiriyah dan Fatchiyah, 2013).

Prospek usaha ternak kambing di Gotzilla Farm, juga didukung oleh topografis, yaitu lokasi peternakan yang searah dengan lokasi wisata. Hal ini dimanfaatkan oleh Gotzilla Farm menjadi agrowisata pendidikan berbasis peternakan. Usaha peternakan pada Gotzilla Farm mampu menangkap peluang yang ada untuk meningkatkan usahnya agar terus berkembang dengan baik. 
Tabel 1. Prospek usaha

\begin{tabular}{ll}
\hline \multicolumn{1}{c}{ Keterangan } & \multicolumn{1}{c}{ Nilai } \\
\hline Jenis Usaha & Peternakan, pengolahan, dan Eduwisata \\
Kepemilikan & Keluarga \\
Jumlah ternak & 50 ekor \\
Produksi susu & 1 liter/hari/ekor \\
Jumlah susu yang diolah & 50 liter/hari \\
Harga jual susu & Rp15.000,00 \\
\hline
\end{tabular}

Analisis SWOT Faktor Lingkungan Internal dan Eksternal

Peternakan Goatzilla Farm yang memiliki usaha ternak kambing Etawa Senduro, yang menghasilkan susu, juga memproduksi produk olahan dari susu kambing. Diantaranya fresh milk, susu pasteurisasi, yogurt susu kambing, masker kefir, sabun susu, dan produk olahan lainnya. Produk susu kambing di indonesia sedang mengalami peningkatan permintaan, sehingga Goatzilla Farm perlu memiliki strategi untuk meningkatkan usahannya agar tidak kalah bersaing. Untuk itu analisis SWOT diperlukan untuk memetakan potensi kekuatan, kelemahan, peluang, dan ancaman yang ada pada saat ini. Analisis SWOT diperoleh dari hasil wawancara disajikan pada Tabel 2 dan 3. Berdasarkan hasil analisis IFAS dan EFAS dapat disajikan nilai skor masing-masing faktor baik internal maupun eksternal sebagai berikut:

- faktor kekuatan (strengths) 2,29

- faktor kelemahan (weaknesses) $\quad 1,18$

- faktor peluang (opportunities) 2,22

- faktor ancaman (threats) $\quad 1,08$

Tabel 2. Hasil analisis SWOT matriks IFAS pengembangan usaha di Goatzilla Farm

\begin{tabular}{|c|c|c|c|c|}
\hline Faktor Internal Dominan & Nilai & Rating & $\begin{array}{c}\text { Bobot } \\
(\%)\end{array}$ & $\begin{array}{c}\text { Bobot X } \\
\text { Rating }\end{array}$ \\
\hline \multicolumn{5}{|l|}{ Strengths (kekuatan) } \\
\hline 1 Memiliki produk yang berkualitas & 4 & 3 & 0.09 & 0.26 \\
\hline 2 Terus melakukan inovasi dan pengembangan produk & 4 & 3 & 0.09 & 0.26 \\
\hline 3 Harga yang kompetitif & 3 & 4 & 0.12 & 0.47 \\
\hline 4 Manajemen yang baik & 4 & 4 & 0.12 & 0.47 \\
\hline 5 Proses produksi dan operasi yang sistematis & 3 & 4 & 0.12 & 0.47 \\
\hline 6 Pertumbuhan laba dan penjualan meningkat & 3 & 4 & 0.09 & 0.35 \\
\hline Sub Total & 21 & 22 & 0.62 & 2.29 \\
\hline \multicolumn{5}{|l|}{ Weaknesses (kelemahan) } \\
\hline 1 Tidak adanya program latihan & 3 & 3 & 0.09 & 0.26 \\
\hline 2 Keterbatasan promosi & 2 & 2 & 0.06 & 0.12 \\
\hline 3 Segmen pasar terbatas & 3 & 4 & 0.06 & 0.24 \\
\hline 4 Tidak tercapainya target penjualan & 2 & 2 & 0.09 & 0.18 \\
\hline 5 Tingkat pendidikan SDM relatif rendah & 2 & 3 & 0.09 & 0.26 \\
\hline 6 Kurangnya tenaga terampil & 3 & 2 & 0.06 & 0.12 \\
\hline Sub Total & 15 & 16 & 0.44 & 1.18 \\
\hline Total & 34 & 38 & 0.97 & 3.21 \\
\hline
\end{tabular}


Berdasarkan matriks IFAS dan EFAS pada Tabel 4, diperoleh strategi SO sebesar 4,51 artinya bahwa strategi utama yang harus diterapkan oleh Goatzilla Farm dalam rangka pengembangan usahanya adalah strategi agresif seperti yang ditunjukkan pada kuadran I. Menurut David (2011) matriks IFAS dan EFAS berperan untuk merangkum dan mengevaluasi kekuatan dan kelemahan dalam menentukan strategi perusahaan. Tujuan penggunaan model ini adalah untuk memperoleh strategi bisnis yang lebih detail

Tabel 3. Hasil analisis SWOT matrik EFAS pengembangan usaha di Goatzilla Farm

\begin{tabular}{|c|c|c|c|c|c|}
\hline \multicolumn{2}{|r|}{ Faktor Eksternal Dominan } & Nilai & Rating & $\begin{array}{c}\text { Bobot } \\
(\%)\end{array}$ & $\begin{array}{c}\text { Bobot X } \\
\text { Rating }\end{array}$ \\
\hline \multicolumn{6}{|c|}{ Opportunities (Peluang) } \\
\hline 1 & Jaminan manfaat produk & 3 & 3 & 0.08 & 0.24 \\
\hline 2 & Pertumbuhan ekonomi yang kian membaik & 3 & 3 & 0.08 & 0.24 \\
\hline 3 & Perkembangan teknologi Informasi & 4 & 4 & 0.11 & 0.43 \\
\hline 4 & Kebijakan pemerintah & 4 & 4 & 0.11 & 0.43 \\
\hline 5 & Pangsa pasar yang potensial & 3 & 4 & 0.11 & 0.43 \\
\hline 6 & Kepercayaan konsumen & 4 & 4 & 0.11 & 0.43 \\
\hline \multicolumn{2}{|r|}{ Sub Total } & 21 & 22 & 0.59 & 2.22 \\
\hline \multicolumn{6}{|c|}{ Threats (Ancaman) } \\
\hline 1 & Persaingan dengan produk susu sapi & 4 & 3 & 0.08 & 0.24 \\
\hline 2 & Persepsi negatif masyarakat terhadap susu kambing & 3 & 2 & 0.05 & 0.11 \\
\hline 3 & Ijin produk susu yang sulit dan mahal & 4 & 4 & 0.05 & 0.22 \\
\hline 4 & Munculnya pendatang baru & 2 & 2 & 0.08 & 0.16 \\
\hline 5 & Konsumen sensitif terhadap harga & 2 & 3 & 0.08 & 0.24 \\
\hline 6 & Harga mesin pengolahan yang mahal & 3 & 2 & 0.05 & 0.11 \\
\hline \multicolumn{2}{|r|}{ Sub Total } & 18 & 16 & 0.41 & 1.08 \\
\hline & Total & 37 & 38.00 & 0.92 & 3.05 \\
\hline
\end{tabular}

Tabel 4. Matriks IFAS dan EFAS

\begin{tabular}{|c|c|c|}
\hline $\mathrm{X}^{-3}$ & $\begin{array}{c}\text { Kekuatan } \\
\text { (Strengths) } \\
\mathrm{S}\end{array}$ & $\begin{array}{c}\text { Kelemahan } \\
\text { (Weaknesses) } \\
\text { W }\end{array}$ \\
\hline Peluang & (Kuadran I) & (Kuadran II) \\
\hline (Opportunities) & Strategi (SO) & Strategi (WO) \\
\hline 0 & $2,29+2,22=4,51$ & $1,18+2,22=3,40$ \\
\hline Ancaman & (Kuadran III) & (Kuadran IV) \\
\hline (Threats) & Strategi (ST) & Strategi (WT) \\
\hline $\mathrm{T}$ & $2,29+1,08=3,37$ & $1,18+1,08=2,26$ \\
\hline
\end{tabular}


Tabel 5. Alternatif strategi pengembangan usaha di Goatzilla Farm

\begin{tabular}{|c|c|c|}
\hline $\begin{array}{l}\text { Faktor } \\
\text { Eksternal }\end{array}$ & $\begin{array}{l}\text { Kekuatan (S) } \\
\text { [1] Memiliki produk yang berkualitas } \\
\text { [2] Terus melakukan inovasi dan } \\
\text { pengembangan produk } \\
\text { [3] Harga yang kompetitif } \\
\text { [4] Manajemen yang baik } \\
\text { [5] Proses produksi dan operasi yang } \\
\text { sistematis } \\
\text { [6] Pertumbuhan laba dan penjualan } \\
\text { meningkat }\end{array}$ & $\begin{array}{l}\text { Kelemahan (W) } \\
\text { [1] Tidak adanya program latihan } \\
\text { [2] Keterbatasan promosi } \\
\text { [3] Segmen pasar terbatas } \\
\text { [4] Tidak tercapainya target } \\
\text { penjualan } \\
\text { [5] Tingkat pendidikan SDM relatif } \\
\text { rendah } \\
\text { [6] Kurangnya tenaga terampil }\end{array}$ \\
\hline $\begin{array}{l}\text { Peluang (0) } \\
\text { [1] Jaminan manfaat produk } \\
\text { [2] Pertumbuhan ekonomi } \\
\text { yang kian membaik } \\
\text { [3] Perkembangan teknologi } \\
\text { Informasi } \\
\text { [4] Kebijakan pemerintah } \\
\text { [5] Pangsa pasar yang } \\
\text { potensial } \\
\text { [6] Kepercayaan konsumen }\end{array}$ &  & 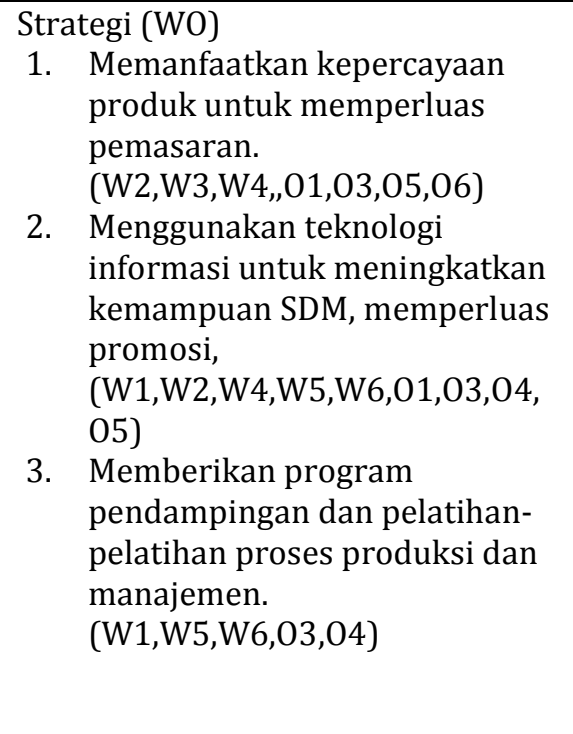 \\
\hline 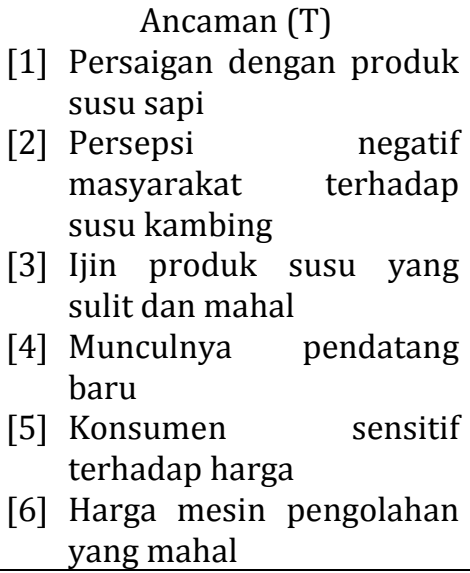 & $\begin{array}{ll}\text { Strategi (ST) } \\
\text { 1. } & \text { Meningkatkan kualitas produk } \\
& \text { susu kambing } \\
& (\mathrm{S} 1, \mathrm{~S} 2, \mathrm{~S} 3, \mathrm{~S} 5, \mathrm{~T} 1, \mathrm{~T} 2, \mathrm{~T} 4, \mathrm{~T} 5) \\
\text { 2. } & \text { Memperbaiki manajemen untuk } \\
& \text { mendapatkan ijin produksi } \\
& (\mathrm{S} 1, \mathrm{~S} 4, \mathrm{~S} 5, \mathrm{~T} 1, \mathrm{~T} 2, \mathrm{~T} 3, \mathrm{~T} 4) \\
\text { 3. } & \text { Memperbaiki manajemen } \\
& \text { keuangan untuk meningkatkan } \\
& \text { investasi pada teknologi } \\
& (\mathrm{S} 3, \mathrm{~S} 4, \mathrm{~S} 5, \mathrm{~S} 6, \mathrm{~T} 1, \mathrm{~T} 3, \mathrm{~T} 5, \mathrm{~T} 6)\end{array}$ & $\begin{array}{ll}\text { Strategi (WT) } \\
\text { 1. } & \text { Meningkatkan kerjasama untuk } \\
& \text { menyediakan bahan baku dan } \\
& \text { penjualan. } \\
& (\mathrm{W} 2, \mathrm{~W} 3, \mathrm{~W} 4, \mathrm{~T} 1, \mathrm{~T} 2, \mathrm{~T} 4, \mathrm{~T} 5, \mathrm{~T} 6) \\
\text { 2. } & \text { Memanfaatkan sarana yang ada } \\
& \text { untuk meningkatkan kualitas } \\
& \text { produk. } \\
& (\mathrm{W} 1, \mathrm{~W} 4, \mathrm{~W} 6, \mathrm{~T} 1, \mathrm{~T} 2, \mathrm{~T} 3, \mathrm{~T} 4, \mathrm{~T} 6) \\
\text { 3. } & \text { Menyediakan Program Pelatihan } \\
& \text { SDM. (W1,W5,W6,T1,T3,T4,T6) }\end{array}$ \\
\hline
\end{tabular}

Alternatif strategi pengembangan usaha di Goatzilla Farm (Tabel 5) yang diperoleh merupakan hasil analisis SWOT yang berupa strategi alternatif untuk dapat digunakan dalam pengembangan usaha goatzilla farm. Menurut Ikhsan dan Aid (2011) analisis SWOT merupakan alat formulasi dalam pengambilan keputusan dan digunakan untuk menentukan strategi yang ditempuh berdasarkan kepada logika untuk memaksimalkan kekuatan dan peluang, akan tetapi secara bersama-sama dapat meminimalkan kelemahan dan ancaman.

\section{Alternatif Strategi Pengembangan Usaha di Goatzilla Farm}

Perumusan alternatif strategi dengan metode SWOT dilakukan dengan penggabungan antara kedua faktor internal (kekuatan dan kelemahan) dengan faktor eksternal (peluang dan ancaman) disajikan pada Tabel 6. 
Matriks implementasi program dan kegiatan pengembangan usaha di Goatzilla Farm ini didukung oleh hasil penelitian (Susanto et al., 2017) yakni prioritas dalam pengembangan usaha peternakan kambing di Kabupaten Lumajang adalah kriteria input, sedangkan alternatif prioritas pengembangan peternakan kambing adalah modal usaha.

Tabel 6. Matriks implementasi program dan kegiatan pengembangan di Goatzilla Farm

\begin{tabular}{|c|c|c|c|c|}
\hline No & Strategi $(\mathrm{S}-\mathrm{O})$ & & Program & Kegiatan \\
\hline 1. & $\begin{array}{l}\text { Mengoptimalkan dan } \\
\text { mengembangkan } \\
\text { kemampuan internal } \\
\text { dengan memanfaatkan } \\
\text { dukungan pemerintah } \\
\text { dan kepercayaan } \\
\text { konsumen. }\end{array}$ & 1. & $\begin{array}{l}\text { Peningkatan } \\
\text { kualitas SDM }\end{array}$ & 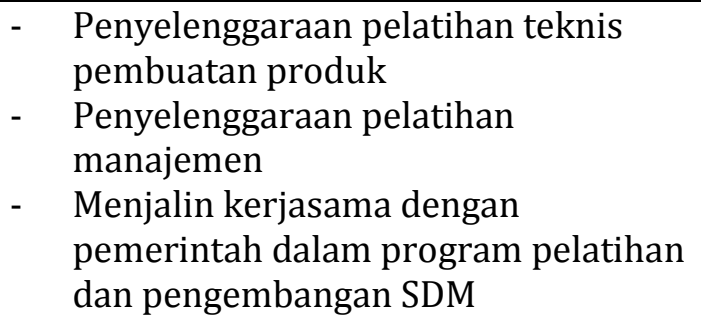 \\
\hline 2. & $\begin{array}{l}\text { Terus berinovasi dalam } \\
\text { pengembangan produk } \\
\text { dengan memanfaatkan } \\
\text { teknologi informasi } \\
\text { untuk menjaga } \\
\text { kepercayaan } \\
\text { konsumen. }\end{array}$ & 2. & $\begin{array}{l}\text { Inovasi produk } \\
\text { dan } \\
\text { pemanfaatan } \\
\text { teknologi } \\
\text { informasi }\end{array}$ & $\begin{array}{ll}\text { - } & \text { Perbaikan kualitas produk secara } \\
\text { terus menerus } \\
\text { - } & \text { Memanfaatkan media sosial dalam } \\
\text { promosi } \\
\text { - }\end{array}$ \\
\hline 3. & $\begin{array}{l}\text { Menjalin kerjasama } \\
\text { dengan pemerintah } \\
\text { dalam penyediaan row } \\
\text { material untuk } \\
\text { memenuhi pangsa } \\
\text { pasar potensial }\end{array}$ & 3. & $\begin{array}{l}\text { Pengembangan } \\
\text { kerjasama }\end{array}$ & $\begin{array}{ll}\text { - } & \text { Pengembangan kerjasama dengan } \\
\text { peternak untuk mendapatkan } \\
\text { ketersediaan bahan baku produksi } \\
\text { - } & \text { Menjalin kerjasama dalam } \\
\text { mengembangkan jaringan pemasaran } \\
\text { produk } \\
\text { - } \\
\text { Menjalin kerjasama dengan } \\
\text { pemerintah dalam program } \\
\text { pengembangan ternak kambing etawa } \\
\text { Senduro }\end{array}$ \\
\hline
\end{tabular}

\section{KESIMPULAN DAN SARAN}

\section{Kesimpulan}

Alternatif strategi yang dapat direkomendasikan dalam usaha di Goatzilla Farm adalah Strategi So (Strengths Opportunities) yakni strategi keunggulan komparatif dimaksudkan untuk menarik keuntungan (comparative advantage), yaitu pertemuan antara peluang dari luar dengan kekuatan yang dimiliki oleh Goatzilla Farm, dengan strategi sebagai berikut:

1. Mengoptimalkan dan mengembangkan kemampuan internal, serta memanfaatkan teknologi informasi untuk meningkatkan kualitas produk. bekerjasama dengan pemerintah, peternak, dan jaringan distribusi untuk menyediakan bahan baku dan meningkatkan penjualan produk.

2. Ancaman yang perlu diwaspadai oleh Gotzilla Farm adalah perijinan, yang perlu disegerakan untuk memperkuat bargaining position. Tanpa adanya perijinan yang mamadai dapat mengancam keberlangsungan usaha yang sedang dijalankan.

\section{Saran}

Mengembangkan usaha peternakan dengan menciptakan inovasi produk olahan lebih spesifik sesuai selera konsumen. Selain itu, Goatzilla Farm dapat diarahkan menjadi sentra pengolahan susu kambing dengan pendekatan konsep agrowisata berbasis peternakan. 


\section{UCAPAN TERIMAKASIH}

Kami mengucapkan terimakasih kepada Politeknik Negeri Jember dan Pusat Penelitian dan Pengabdian kepada Masyarakat (P3M) atas anggaran tahun 2017 yang telah diberikan dalam kegiatan penelitian ini. Melalui kegiatan ini kami mampu menjalin kerjasama yang baik dengan masyarakat terutama peternakan goatzilla farm. Semoga dengan adanya kegian ini mampu membawa kebermanfaatan baik bagi institusi maupun masyarakat.

\section{DAFTAR PUSTAKA}

David, Fred R. (2011). Strategic Management Concept and Cases. (13th ed). Essex, UK: Pearson Education.

Dinas Pertanian Kabupaten Lumajang. 2018. Data populasi ternak kecil kab. Lumajang, periode: tribulan II 2018. https://lumajangkab.go.id/profil/terna k_kecil.php. Diakses tanggal 10 Agustus 2018.

Ikhsan, S. dan A. Aid. 2011. Analisis SWOT untuk merumuskan strategi pengembangan komoditas karet di kabpaten pulang pisau, kalimantan tengah. Jurnal Agribisnis Pedesaan 1(3): 166-177.

Khoiriyah, L.K. dan Fathiyah. 2013. Karakter biokimia dan prifil protein yogurt kambing PE di fermentasi bakteri asam laktat (BAL). The Journal of Experimental Life Science. 3(1). universitas Brawijaya.

Menteri Pertanian. 2014. Keputusan Menteri Pertanian Republik Indonesia Nomor 1055/Kpts/SR.120/10/2014 Tentang Penetapan Galur Kambing Senduro. Kementerian pertanian. Jakarta.

Nazir, M. 2003. Metodologi Penelitian. Ghalia Indonesia. Jakarta.

Rangkuti, F. 2006. Analisis SWOT Teknik Membedah Kasus Bisnis. Reorientasi Konsep Perencanaan Strategis Untuk menghadapi Abad 21. PT Gramedia Pustaka Utama. Jakarta.

Susanto, A.D, Soetriono, dan A. Supriono. Analisis perwilayahan dan strategi pengembangan peternakan kambing di Kabupaten Lumajang. Jurnal IlmuIlmu Sosial. 12(2): 107-120.

Singarimbun dan Effendi. 1995. Metode Penelitian Survei. LP3ES. Jakarta. 